\title{
Interferon-like activity produced by anterior kidney leucocytes of rainbow trout stimulated in vitro by infectious hematopoietic necrosis virus or Poly I:C
}

\author{
James Congleton ${ }^{1,2, *}$, Boling Sun ${ }^{2}$ \\ ${ }^{1}$ National Biological Service, Idaho Cooperative Fish and Wildlife Research Unit, ${ }^{2}$ Department of Fish and Wildlife Resources, \\ University of Idaho, Moscow, Idaho 83843, USA
}

\begin{abstract}
Leucocytes from the anterior kidneys of rainbow trout Oncorhynchus mykiss produced an interferon-like cytokine (ILC) or cytokines when stimulated with free infectious hematopoietic necrosis (IHN) virus, with cell membrane-associated (CMA) IHN virus on glutaraldehyde-fixed chinook salmon embryo cells, or with the synthetic polyribonucleotide Poly I:C. Peak yields of ILC were similar in leucocyte cultures stimulated by free virus or by CMA virus at optimal multiplicities of infection. The antiviral activity had both acid-resistant and acid-labile components, indicating production of several cytokines. Moreover, activity produced by free virus-stimulated leucocytes was significantly $(p \leq 0.05)$ more resistant to treatment at $\mathrm{pH} 2$ than was activity produced by CMA virus-stimulated leucocytes. Leucocyte populations enriched for macrophages (but not for neutrophils or lymphocytes) demonstrated a significantly enhanced capacity for ILC production after stimulation by Poly I:C or free IHN virus. The capacity of macrophages for ILC production may be an important element of the nonspecific resistance of salmonids to IHN virus.
\end{abstract}

KEY WORDS: Interferon $\cdot$ IHN virus $\cdot$ Rainbow trout $\cdot$ Macrophage $\cdot$ Leucocyte $\cdot$ Cytokine

\section{INTRODUCTION}

Type I interferons (IFNs) are pH-resistant cytokines produced by many cell types in vertebrate animals in response to stimulation by viruses and other intracellular pathogens. The essential role of type I IFNs (IFN- $\alpha$ and IFN- $\beta$ ) in host resistance to viruses is shown by the decreased resistance to viral challenge of animals lacking a functional type I IFN receptor (Müller et al. 1994 ) or treated with anti-IFN- $\alpha / \beta$ antibodies (Gresser 1984). One major action of IFN is to induce products in host cells that inhibit the translation of viral mRNA, but in higher vertebrates interferons have also been shown to increase the nonspecific antiviral activity of natural killer cells and macrophages, increase virus-specific cytotoxicity by T-cells, and induce other antiviral cytokines (reviewed by De Maeyer \& De MaeyerGuignard 1988).

•E-mail: jconglet@uidaho.edu
Infectious hematopoietic necrosis (IHN) is a rhabdoviral disease that can cause devastating epizootics or chronic mortality in cultured salmonid fish populations (Wolf 1988). Effective control measures are not available, although experimental vaccines are under development (Winton 1991). If methods could be developed for enhancement of nonspecific (non-immune) resistance to IHN, these methods could provide some protection for susceptible fish populations, or could be used in conjunction with effective vaccines when they become available.

Several studies have supported the idea that interferon-like cytokines (ILC) may play a role in nonspecific resistance to rhabdoviral diseases in fish. Interferon-like activity was demonstrated in the serum of rainbow trout Oncorhynchus mykiss following experimental infection with IHN virus (de Kinkelin \& Le Berre 1974) and with a related rhabdovirus, viral haemorhagic septicaemia (VHS) virus (de Kinkelin \& Dorson 1973, de Kinkelin et al. 1982, Renault et al. 1991). Also, leukocytes from the anterior kidney and 
peripheral blood of rain.bow trout produced ILC when stimulated in vitro with VHS virus (Rogel-Gaillard et al. 1993). Interferon-like cytokines can protect against rhabdoviral disease: de Kinkelin et al. (1982) reported that rainbow trout fry were passively protected against an in vivo challenge with VHS virus by injection with serum harvested from rainbow trout challenged with VHS virus 2 d previously. Similarly, rainbow trout alevins injected with supernatant from cultures of rainbow trout anterior kidney cells stimulated in vitro with VHS virus were protected against challenge with VHS virus (Rogel-Gaillard et al. 1993). Chum salmon Oncorhynchus keta and sockeye salmon Oncorhynchus nerka treated with the synthetic IFN inducer polyriboinosinic-polyribocytidylic acid (Poly I:C) developed an antiviral response that delayed and decreased viral replication and decreased mortality after challenge with IHN virus (Eaton 1990).

Understanding of the r vie of ILC in nonspecific resistance of fish to viruses can be improved by studying the interactions of viruses with their fish host cells in vitro. Of particular interest is the capacity for ILC production by cell types that occur at primary sites of viral infection, because an early ILC response at the primary focus of infection may limit or prevent further viral replication and systemic dissemination (Morahan et al. 1991). The salmonid kidney is a target organ for IHN virus, with viral replication localized in the hematopoietic tissue (Yamamoto \& Clermont 1990, Yamamoto et al. 1990). The virus has been shown to replicate in vitro in leucocytes from the anterior kidney of rainbow trout (Chilimonczyk \& Winton 1994). In the present study, we used the interferon assay of Renault et al. (1991) in order to examine the capacity of IHN virus- and Poly I:C-stimulated leucocytes from the anterior kidney of rainbow trout for in vitro ILC production. Sources of variation in the assay were identified, and modifications were made to improve the accuracy and precision of the method. In addition, we attempted to identify the cell types responsible for ILC production.

\section{MATERIALS AND METHODS}

Fish. Virus-free juvenile rainbow trout (ages 3 to 12 mo post-hatch, weights 20 to $100 \mathrm{~g}$ ) were provided by Clear Springs Foods Inc., Buhl, Idaho, USA. Fish were held in $200 \mathrm{l}$ circular tanks supplied with well water at 11 to $15^{\circ} \mathrm{C}$ and were fed a semi-moist pelleted food (Biodiet Grower, Bioproducts Inc., Warrenton, OR, USA) at levels ranging from 70 to $100 \%$ of the full recommended ration. Fish were acclimated to laboratory conditions for $3 \mathrm{wk}$ or longer prior to use.
Preparation of leucocyte suspensions from the anterior kidney. Fish were killed by a blow to the head. The anterior one-third of the kidney was removed and pressed through a sterile stainless steel screen (100 mesh) into $10 \mathrm{ml}$ cold Hanks' balanced salt solution without calcium and magnesium (HBSS-CMF) supplemented with sodium bicarbonate $\left(0.35 \mathrm{mg} \mathrm{ml}^{-1}\right)$ and bovine serum albumin $(0.1 \%)$ and adjusted to $\mathrm{pH}$ 7.6. The anterior kidney (AK) cell suspensions were pelleted and resuspended in $5 \mathrm{ml}$ HBSS-CMF, layered over $5 \mathrm{ml}$ of Histopaque 1077, and centrifuged at $1300 \times g$ for $30 \mathrm{~min}\left(10^{\circ} \mathrm{C}\right)$. Cells at the interface were harvested, diluted to $10 \mathrm{ml}$ with $\mathrm{HBSS}-\mathrm{CMF}$, pelleted, and resuspended in $2 \mathrm{ml}$ Liebovitz-15 medium (L-15) supplemented with $100 \mathrm{U} \mathrm{ml}^{-1}$ penicillin and $100 \mu \mathrm{g}$ $\mathrm{ml}^{-1}$ streptomycin and adjusted to pH 7.6. Fetal bovine serum (FBS) was not used in the medium because preliminary tests indicated that ILC production was decreased if serum was added. Aliquots of the cell suspensions were counted in a hemocytometer and medium added to adjust leucocyte densities as desired. All reagents were purchased from Sigma Chemical Company, St. Louis, Missouri, USA.

Treatment of cell suspensions with inducers. Antiviral cytokine activity was induced by culturing $\mathrm{AK}$ cell suspensions or adherent cells at $16^{\circ} \mathrm{C}$ in the presence of either (1) IHN virus, strain 220-90, which was originally isolated from rainbow trout in the Hagerman Valley, Idaho, USA (LaPatra et al. 1991), (2) fixed cell monolayers that had been previously infected with IHN virus, or (3) the interferon inducer Poly I:C (Sigma P-0913). Stock virus was titered by plaque assay (Burke \& Mulcahy 1980) on monolayers of epithelioma papillosum cyprini cells (Fijan et al. 1983) with an overlay of Eagle's minimum essential medium (Sigma) containing $0.75 \%$ methylcellulose, $2 \%$ FBS, and antibiotics. Various dilutions of stock IHN virus or Poly I:C in L-15 were added to equal volumes of $\mathrm{AK}$ cell cultures in either 1.7 or $6 \mathrm{ml}$ polypropylene tubes (Fisher Scientific, Pittsburg, Pennsylvania, USA), or AK cell cultures were added to tissue-culture plates (Corning Laboratory Sciences, Corning, New York, USA) containing monolayers of fixed, infected cells (detailed procedure described below). Final AK cell densities were $2 \times 10^{6}$ cells $\mathrm{ml}^{-1}$, except as otherwise noted Tubes were gently rocked during the induction period After completion of the induction period, supernatants were recovered by centrifugation.

Inactivation of residual virus. Residual virus in supernatants from IHNV-treated cultures was inactivated by addition of $4 \mathrm{~N} \mathrm{HCl}\left(11.5 \mu \mathrm{l} \mathrm{ml}^{-1}\right)$ to the supernatants, reducing the $\mathrm{pH}$ to 2 ; after overnight incubation at $4{ }^{\circ} \mathrm{C}$, the $\mathrm{pH}$ was restored to 7.6 by addition of $4 \mathrm{~N} \mathrm{NaOH}$. Alternatively, residual IHN virus was inactivated by exposure to ultraviolet light (two $15 \mathrm{~W}$ 
G15T8 germicidal lamps at $20 \mathrm{~cm}$ for $30 \mathrm{~min}$ ) This method allowed subsequent determination of the lability of IHNV-induced ILC activity in relation to low $\mathrm{pH}$ treatment.

Assay for ILC activity. The method used to assay AK cell supernatants for ILC activity was adapted from the method described by Renault et al. (1991) for assay of ILC activity in whole-body homogenates of rainbow trout fry. The modified method differs in all specific details from the original method, and so is described in detail here.

The chinook salmon embryo (CHSE-214; American Type Culture Collection CRL 1681) cell line was selected for use in the assay because it does not produce ILC activity (MacDonald \& Kennedy 1979), and so would not be stimulated by Poly I:C in the AK cell supernatants. The CHSE-214 cells were cultured in $150 \mathrm{~cm}^{2}$ tissue culture flasks (Corning) with $40 \mathrm{ml}$ RPMI-1640 medium supplemented with sodium bicarbonate ( $2 \mathrm{mg} \mathrm{ml}^{-1}$ ), $100 \mathrm{U} \mathrm{ml}^{-1}$ penicillin and $100 \mu \mathrm{g}$ $\mathrm{ml}^{-1}$ streptomycin, and $8 \%$ FBS. Two days prior to use, CHSE cells grown to confluency were put into suspension by treatment with trypsin-EDTA solution (HBSSCMF with $0.5 \%$ trypsin and $0.02 \%$ disodium ethylenediamine-tetraacetic acid), diluted to $80 \mathrm{ml}$, and split into 2 flasks. The day of the assay, the CHSE cells were resuspended, adjusted to $5 \times 10^{5}$ cells $\mathrm{ml}^{-1}$ (optical density of 0.11 to 0.12 at $550 \mathrm{~nm}$ ), and seeded into 96 well tissue culture plates (Corning) at $0.15 \mathrm{ml}$ well ${ }^{-1}$ Monolayers in the 96 -well plates were $95 \%$ confluent and ready for use after 5 to $6 \mathrm{~h}$. The plates were inverted and blotted on sterile paper immediately prior to addition of AK cell supernatants.

Supernatants from stimulated AK cell cultures were diluted in doubling steps from 1:4 to 1:64 with RPMI medium containing $4 \%$ FBS and transferred to the 96 -well plates $\left(0.1 \mathrm{ml}\right.$ well $\left.{ }^{-1}\right)$, with each dilution replicated in 6 wells. The CHSE monolayers were treated with the $\mathrm{AK}$ cell supernatants for $16 \mathrm{~h}$ at $16^{\circ} \mathrm{C}$, the plates inverted and blotted, and the CHSE cells challenged by adding 5000 plaque-forming units of IHN virus (strain 220-90) in $0.15 \mathrm{ml}$ RPMI medium with $2 \%$ FBS to each well. In addition to the 6 wells treated with each supernatant dilution and challenged with virus, 16 wells were treated but not challenged, providing a measure of cell density in the absence of any viral cytopathic effect (maximum cell density). An additional 6 wells were not treated or challenged, providing an estimate of maximum cell density in the absence of both cytopathic and possible ILC stimulatory or inhibitory effects, and 6 wells were untreated and challenged, providing an estimate of the cell density resulting from cytolysis of cells unprotected by previous exposure to ILC (minimum cell density).
The plates were incubated $72 \mathrm{~h}$ at $16^{\circ} \mathrm{C}$, the medium was removed, and the monolayers fixed and stained by adding $0.1 \mathrm{ml}$ of a $20 \%$ ethanol solution containing $1 \%$ crystal violet to each well. The extent of virus-induced cytolysis was quantified by reading the optical density (OD) of the stained monolayers with an ELISA reader (Model EL309, Bio-Tek, Winooski, VT, USA) at $600 \mathrm{~nm}$. The percent protection $\left(\% P_{x}\right)$ provided by treatment of the CHSE cells with each dilution $(x)$ of A.K cell supernatant was calculated as:

$\% P_{x}=$

Mean OD(treated, challenged) - Mean OD(min density) $\times 100$ Mean $O D($ max density) - Mean OD(min density)

These data were plotted against reciprocals of the corresponding supernatant dilutions on log-probit paper (Sprague 1969), yielding linear regressions over a range from $\% P_{x}=5 \%$ to $\% P_{x}=95 \%$. The dilution providing $50 \%$ protection was estimated by interpolation, and ILC activity was calculated in tissue culture protective dose units $\mathrm{ml}^{-1}\left(\mathrm{TCPD}_{50} \mathrm{U} \mathrm{ml}^{-1}\right)$ as $10 \times$ the reciprocal of the dilution providing $50 \%$ protection.

Supernatants obtained from Poly I:C-stimulated AK cell cultures of 4 large rainbow trout were pooled, aliquoted, and frozen at $-80^{\circ} \mathrm{C}$ for use as an ILC reference standard. An aliquot of the reference standard was included in every assay

Properties of ILC. The resistance of ILC activity to low $\mathrm{pH}$ was determined by addition of $\mathrm{HCl}$, with subsequent restoration of $\mathrm{pH}$ by addition of $\mathrm{NaOH}$ as previously described. Supernatants from AK leucocytes stimulated by Poly I:C ( $\mathrm{n}=6$ fish) were treated at $\mathrm{pH} 2$ overnight. Similarly, supernatants from matched cultures of leucocytes ( $n=5$ fish) stimulated by either free IHN virus or by cell membrane-associated (CMA) IHN virus were treated at $\mathrm{pH} 2$ overnight. Control aliquots of each supernatant were maintained at pH $7.6\left(4^{\circ} \mathrm{C}\right)$. All virus-induced supernatants were exposed to UV light prior to assay.

Resistance to trypsin was determined by incubation of supernatants in the presence or absence of $0.4 \mathrm{mg}$ $\mathrm{ml}^{-1}$ trypsin (Type II) for 1 h at $37^{\circ} \mathrm{C}$, followed by addition of $0.4 \mathrm{mg} \mathrm{ml}^{-1}$ soybean trypsin inhibitor Resistance to RNase was determined by incubation in the presence or absence of $0.04 \mathrm{mg} \mathrm{ml}^{-1}$ RNase (Type I-AS) for $30 \mathrm{~min}$ at $37^{\circ} \mathrm{C}$. Activity of the RNase was confirmed by treatment of yeast tRNA, followed by gel electrophoresis of the digestion products. Temperature resistance was determined by heating supernatants to 37,45 , and $56^{\circ} \mathrm{C}$ for $30 \mathrm{~min}$ ( $\mathrm{n}=3$ fish).

To determine if ILC activity was lost by absorption on tissue culture-treated plasticware or glutaraldehydefixed CHSE cell monolayers, aliquots of ILC-containing supernatants were incubated overnight $\left(15^{\circ} \mathrm{C}\right)$ in $6 \mathrm{ml}$ polypropylene tubes or in 6 well polystyrene tissue 
culture plates with or without fixed CHSE cell monolayers. Supernatant volumes were adjusted to $0.15 \mathrm{ml}$ $\mathrm{cm}^{-2}$ surface area. Control supernatants were stored frozen at $-80^{\circ} \mathrm{C}$, and test supernatants were also frozen and thawed before assay.

Dose response to free and CMA IHN virus. Matched aliquots of AK cell suspensions from individual rainbow trout $(n=6)$ were used to determine dose-response curves for ILC induction by free and CMA virus. To determine the response of rainbow trout AK leucocytes to stimulation with free IHN virus at various multiplicities of infection (MOI), cells were diluted to $2 \times 10^{6} \mathrm{ml}^{-1}$ and cultured for $24 \mathrm{~h}$ with IHN virus at MOI ranging from 0.5 to 8 in doubling steps. The response of AK leucocytes to stimulation by CMA IHN virus was determined by an adaptation of the protocol of Capobianchi ct al. (1985). Confluent CHSE cell monolayers in 6 well tissue culture plates $\left(1.2 \times 10^{6}\right.$ cells well $\left.{ }^{-1}\right)$ were infected with doubling dilutions of virus a $\mathrm{MOl}$ ranging from 0.06 to 2. After absorption of the diluted virus $\left(0.3 \mathrm{ml} \mathrm{well}^{-1}\right)$ on the CHSE cells for 40 min on a rocker platform, $2.7 \mathrm{ml}$ of RPMI media with $4 \%$ FBS were added per well and the cells were cultured for $24 \mathrm{~h}$. The cells were washed twice with phosphate-buffered saline (PBS) and fixed with $0.25 \%$ glutaraldehyde in PBS for $10 \mathrm{~min}$ at $4^{\circ} \mathrm{C}$. The cells were again washed twice with PBS and once with PBS containing $0.2 \%$ bovine serum albumin. Suspensions of rainbow trout AK leucocytes $(3 \mathrm{ml}, 2 \times$ $10^{6}$ cells $\mathrm{ml}^{-1}$ ) were added to the wells containing the fixed CHSE cell monolayers and cultured for $24 \mathrm{~h}$. Supernatants were recovered and assayed for ILC activity as previously described.

ILC production by adherent, nonadherent, and unseparated leucocyte fractions. Adherent leucocytes were removed from rainbow trout $\mathrm{AK}$ cell suspensions by incubation in 6 well polystyrene tissue culture plates ( $3 \mathrm{ml} \mathrm{well}^{-1}$ at $2 \times 10^{6}$ cells $\left.\mathrm{ml}^{-1}\right)$. After $2 \mathrm{~h}$, nonadherent cells were resuspended by flushing with a pipet and reseeded in a second 6 well plate. After an additional $2 \mathrm{~h}$ incubation, nonadherent cells were recovered, diluted to $2 \times 10^{6}$ cells $\mathrm{m.l}^{-1}$, and stimulated for $24 \mathrm{~h}$ by Poly I: $\mathrm{C}$ in polypropylene tubes ( $\mathrm{n}=4 \mathrm{fish}$ ), or by CMA IHN virus ( $\mathrm{MOI}=0.5$ ) in 6 well tissue culture plates ( $\mathrm{n}=4$ fish). Matching control cultures of unseparated leucocytes from the same individual fish were similarly stimulated with Poly I:C or CMA IHN virus. Supernatants from nonadherent and unseparated cel]. cultures were assayed for ILC activity as previously described.

A second set of experiments was performed to compare ILC production by adherent, nonadherent and unseparated AK leucocytes under identical culture conditions. Adherent cells were separated from nonadherent cells by incubating rainbow trout AK cell suspensions $\left(3 \mathrm{ml}\right.$ at $5 \times 10^{6}$ cells $\mathrm{ml}^{-1}$ ) in $50 \mathrm{ml}$ polypropylene beakers (Fisher), which were determined not to absorb ILC activity. Matching aliquots of the original unseparated $A K$ cell suspensions from the same individual fish were reserved in polypropylene tubes with gentle rocking. After $2 \mathrm{~h}$, nonadherent cells were resuspended with a pipet and removed; the remaining adherent cells were washed 3 times with $2 \mathrm{ml} \mathrm{L}-15$ and the washes pooled. Aliquots of the nonadherent cell suspensions and of the pooled washes were counted and the number of adherent cells remaining in the beakers estimated as the difference between numbers of cells seeded and numbers of cells recovered. Fresh medium ( 2 to $3 \mathrm{ml} \mathrm{L}-15$ ) was added to the beakers to produce adherent cell densities of $2 \times 10^{6}$ cells $\mathrm{ml}^{-1}$ i nonadherent and unseparated cell suspensions were also adjusted to $2 \times 10^{6}$ cells $\mathrm{mi}^{-1}$ and reseeded in sterile bedkers. The cultures ( $\mathrm{n}=3$ fish with each inducer) were stimulated with Poly I:C $\left(50 \mu \mathrm{g} \mathrm{ml}^{-1}\right)$ or with free IHN virus (MOI = 2) for $24 \mathrm{~h}$. Culture supernatants were assayed for ILC activity as previously described.

After removal of supernatants, adherent cells were freed from the beakers by scraping with a rubber spatula, and aliquots of the adherent, nonadherent, and unseparated cell suspensions were deposited on glass slides by cytocentrifugation (Shandon Inc., Pittsburg, PA, USA). The slides were fixed in formaldehyde vapor, stained with Sudan Black B, and counterstained with Wright's stain. Macrophages were distinguished from Iymphocytes and mature neutrophils by cellular morphology (size, shape, and position of nucleus), and from immature neutrophils by a negative response to Sudan Black staining (Congleton et al. 1990).

Statistical analyses. Linear regression analysis was used to evaluate the relationship between optical density ranges for individual microtiter plates and estimated ILC activities for a repeatedly assayed ILC reference standard, and to determine if ILC production was significantly correlated with the numbers of macrophages in cell cultures. Friedman's test, a nonparametric 2-way analysis of variance by ranks for matched samples, was used to test for differences in ILC production between adherent, nonadherent, and unseparated AK cell cultures. Paired t-tests were used for other comparisons of matched samples. Statistical analyses were performed with Statview statistical software (Abacus Concepts, Berkeley, CA, USA). Results are re ported as mean values $\pm S E M$ throughout this paper.

\section{RESULTS}

\section{Kinetics of interferon-like cytokine production}

Antiviral cytokine activity was not detectable in supernatants from raimbow trout $\mathrm{AK}$ cell cultures 
stimulated for 2 or $8 \mathrm{~h}$ by Poly I:C or free IHN virus in either of 2 trials, but ILC titers of 170 to 280 TCPD $_{50}$ $\mathrm{U} \mathrm{ml}^{-1}$ were measured in supernatants from cultures stimulated for $24 \mathrm{~h}$. Titers produced by Poly l:C-stimulated leucocytes changed little between $24 \mathrm{~h}$ and 48 or $72 \mathrm{~h}$, but titers produced by IHN virus-stimulated leucocytes continued to increase up to $72 \mathrm{~h}$, reaching titers nearly 4 -fold greater than the 24 h titers (Fig. 1). Supernatants from unstimulated AK cell suspensions had negligible activity $\left(<5 \mathrm{U} \mathrm{ml}^{-1}\right)$.

\section{Effect of AK cell density on ILC production}

AK cell suspensions ( $\mathrm{n}=4$ fish) diluted to $0.5,1,2$ and $4 \times 10^{6}$ cells $\mathrm{ml}^{-1}$ and stimulated with Poly I:C produced ILC activities per $10^{6}$ cells of $290 \pm 94$ (mean \pm SEM), $439 \pm 92,469 \pm 71$, and $308 \pm 53 \mathrm{TCPD}_{50} \mathrm{U} \mathrm{ml}^{-1}$. Therefore, ILC production per $10^{6}$ cells was highest at $1 \times 10^{6}$ and $2 \times 10^{6}$ cells $\mathrm{ml}^{-1}$ and declined at higher and lower cell densities. A density of $2 \times 10^{6}$ cells $\mathrm{ml}^{-1}$ was selected for routine use.

\section{Kinetics of induction of viral resistance in CHSE cells}

The resistance of CHSE cells to viral challenge was increased after $1 \mathrm{~h}$ treatment with supernatants from Poly I:C-stimulated AK leucocytes, was maximum after 8 to $18 \mathrm{~h}$ treatment, and declined at 20 and $24 \mathrm{~h}$ (Fig. 2). The development of resistance followed almost identical time courses in trials with low-titer and

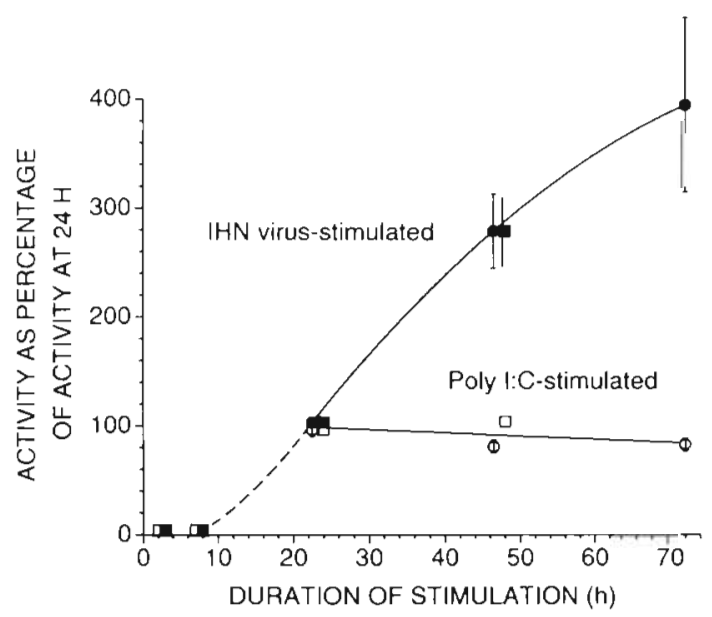

Fig. 1. Production of interferon-like cytokine (ILC) activity by anterior kidney $(\mathrm{AK})$ leucocytes of rainbow trout after various periods of stimulation with Poly I:C $\left(25 \mu \mathrm{g} \mathrm{m}^{-1} ; \square, 0\right)$ or infectious hematopoietic necrosis (IHN) virus (3.8 multiplicity of infection; $\mathbf{\square} \bullet$ in 2 trials with each inducer. Activity is shown as mean percent $( \pm \mathrm{SE})$ of activity observed at $24 \mathrm{~h}$ in each trial. Sample sizes were 4 or 5 fish, except that pooled cells from 3 fish were used in the second Poly I:C trial ( $\square$ )

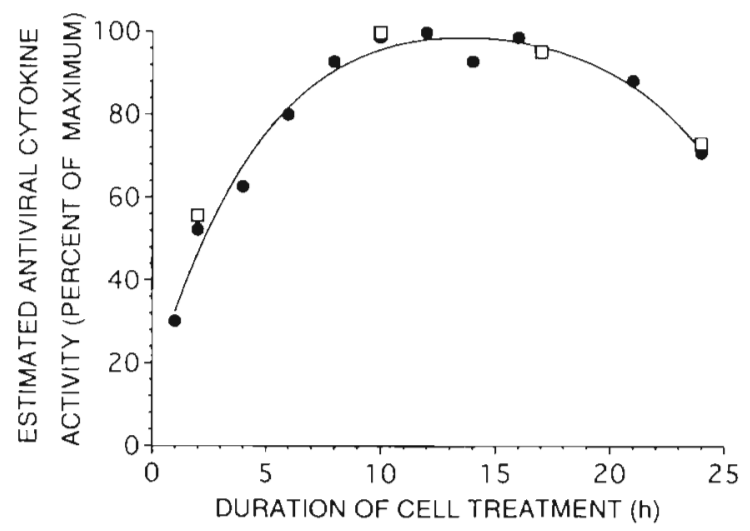

Fig. 2. Protection of CHSE cell monolayers against cytopathic effect of IHN virus after various periods of treatment with ILCcontaining supernatants. Activity is shown as percent of maximum activity observed in each of 2 trials $(\bullet, 0)$. Maximum ILC activities were $320 \mathrm{U} \mathrm{ml}^{-1}$ in Trial 1 and $86 \mathrm{U} \mathrm{ml}^{-1}$ in Trial 2

high-titer supernatants. An overnight treatment period of $16 \mathrm{~h}$ was selected for routine use. The resistance of CHSE cells to viral challenge was not increased by $16 \mathrm{~h}$ exposure to Poly I: $\mathrm{C}\left(25 \mu \mathrm{g} \mathrm{m} \mathrm{m}^{-1}\right)$, or to IHN virus inactivated by treatment at $\mathrm{pH} 2$ or with UV light.

\section{Sources of variation in assay results}

The intra-assay coefficient of variation (CV) for a pooled ILC-containing supernatant assayed 10 times on 5 plates was $10.2 \%$, with titers ranging from 219 to 302 TCID $_{50} \mathrm{U} \mathrm{ml}^{-1}$. The inter-assay CV for aliquots of a pooled supernatant frozen at $-80^{\circ} \mathrm{C}$ and assayed on 20 occasions was $46.6 \%$. In routine practice, this relatively high inter-assay CV was greatly reduced by including a reference standard (RS) with each assay so that a correction factor (RS mean titer for all assays)/ (RS titer for particular assay) could be estimated and applied to sample titers (Finter 1981, Renault et al. 1991). For example, the inter-assay CV for a pooled supernatant assayed on 7 occasions was reduced from 42.9 to $10.3 \%$ by this procedure.

OD ranges (i.e. maximum OD - minimum OD) varied between plates within an assay and between assays due to unavoidable variations in CHSE cell seeding densities or growth rates and in viral cytopathic effect. Examination of data from 26 assays (Fig. 3) indicated a negative correlation $\left(r^{2}=0.68, p<0.0001\right)$ between estimated log titers for a laboratory reference standard and $\log$ OD ranges. The regression slope was 1.0 , indicating that titers were directly inversely proportional to ODs. Consequently, titers for all plates were routinely adjusted to correspond to a standard OD range of 2.0 by a calculation based on the inverse proportionality between ILC titer and OD range: adjusted ILC titer 


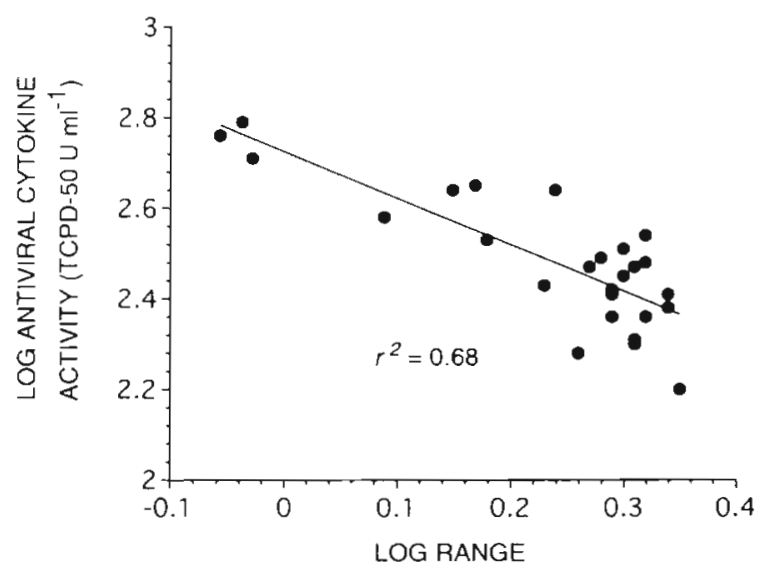

Fig. 3. Relationship between optical density range (maximum OD - minimum OD for assay) and estimated ILC activity of a laboratory reference standard (pooled supernatant from Poly

I:C-stimulated rainbow trout AK leucocytes) in 26 assays

= (calculated ILC titer)(observed plate OD range/2.0). Use of this procedure substantially reduced the intraassay CV for assays with high ( $\geq 0.2 \mathrm{OD}$ units) plate-toplate variance in OD range.

Intrapopulation variation in the response of $\mathrm{AK}$ leucocytes of individual fish to stimulation by Poly $\mathrm{I}$ : $\mathrm{C}$ or IHN virus was large. Coefficients of variation for ILC activity produced by Poly I:C- and IHN virus-stimulated AK leucocytes were 57.8 and $63.6 \%$ ( $n=20$ fish). As the CV attributable to intra-assay methodological error was only about $10 \%$, most of this intrapopulation variation was due to differences in the ability of cells from individual fish to respond to Poly I:C or IHN virus.

\section{Properties of ILC}

The ILC activity produced by both Poly I:C- and IHN virus-stimulated rainbow trout $\mathrm{AK}$ cell cultures had $\mathrm{pH}$-resistant and pH-labile components. Supernatants from Poly I:C-induced cultures ( $n=6$ fish) retained 65 $\pm 1.1 \%$ of ILC activity after $1 \mathrm{~h}$ at $\mathrm{pH} 2$ and $62 \pm 7.0 \%$ after overnight treatment at $\mathrm{pH} 2$. Overnight treatment at $\mathrm{pH} 3$ or $\mathrm{pH} 4$ resulted in losses of activity similar to those observed after treatment at $\mathrm{pH} 2$. The ILC activity produced by free virus-stimulated leucocyte cultures was significantly ( $p<0.001$, paired $t$-test) more resistant $(76.6 \pm 3.0 \%$ retained) to overnight treatment at $\mathrm{pH} 2$ than was the activity produced by matching CMA virus-stimulated cultures $155.7 \pm 3.4 \%$ retained; Table 1). Exposure of supernatants to UV light for up to $1 \mathrm{~h}$ did not reduce ILC activity.

Treatment of ILC-containing supernatants with RNase did not reduce activity, but all activity was destroyed by treatment with trypsin. The activity was temperature-labile: after treatment at 37,45 and $56^{\circ} \mathrm{C}$ for $30 \mathrm{~min}, 62,8$ and $0 \%$ of ILC activity produced by free IHN virus-stimulated AK cell cultures remained. No activity was lost after freezing and thawing.

Overnight incubation of Poly I:C-induced supernatants in tissue culture plates resulted in an almost complete loss of ILC activity (Table 2). In contrast, matched supernatant aliquots incubated in polypropylene tubes retained $85.6 \pm 5.6 \%(n=3)$ of the original activity, i.e. when compared with activity of frozen

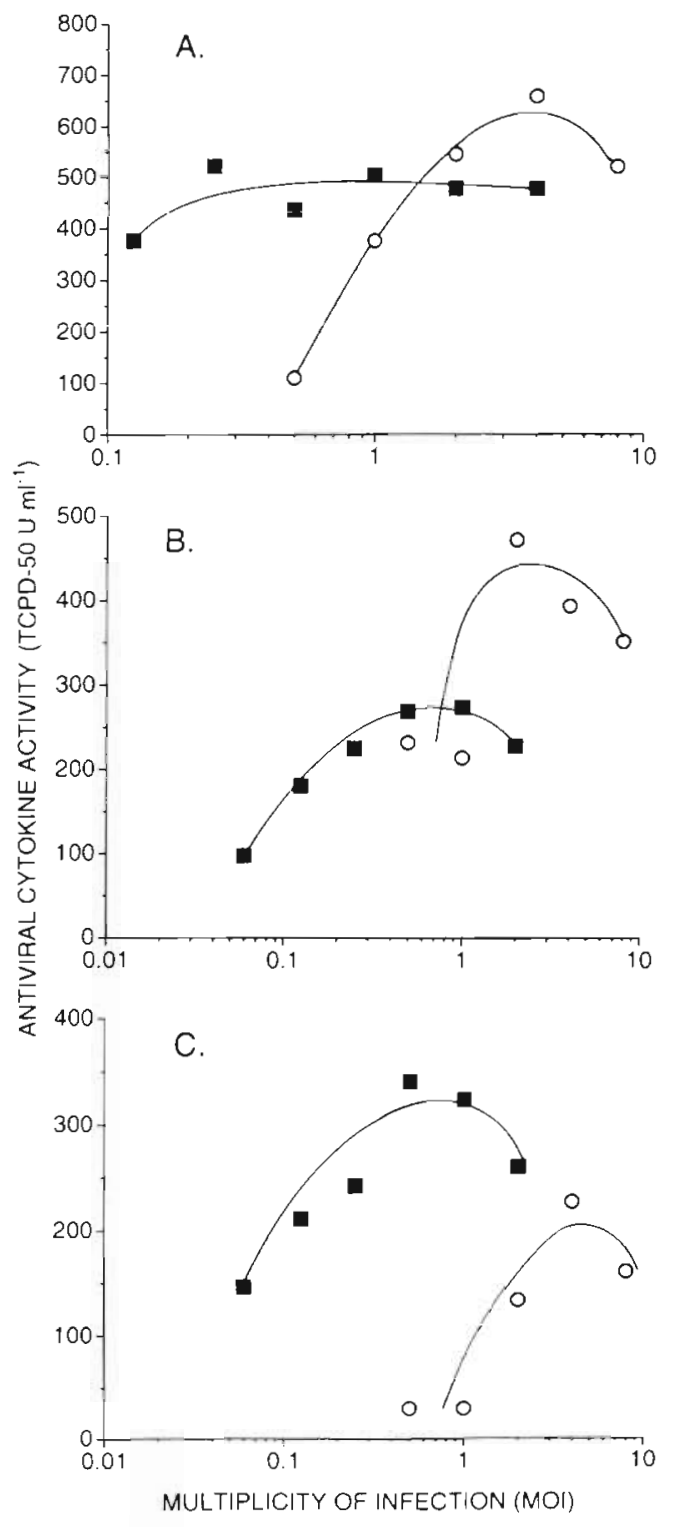

Fig. 4. Production of ILC activity by AK leucocytes of 3 rainbow trout $(A, B, C)$ stimulated with free infectious IHN virus (O) or with cell membrane-associated (CMA) IHN virus expressed on the cell membrane of infected, glutaraldehydefixed CHSE cells ( at various multiplicities of infection. Multiplicities of infection are not directly comparable for trials with free and CMA virus; see 'Materials and methods' for explanation 
supernatant thawed immediately before assay (data not shown). The ILC activity induced by stimulation with either free or CMA IHN virus was absorbed on tissue culture plates to a much smaller extent (45 to $55 \%$ retained) than was Poly I:Cinduced activity (Table 2). Absorption of activity was considerably reduced in tissue culture plates containing fixed CHSE cell monolayers (Table 2).

\section{Dose response to free and CMA IHN virus and Poly I:C}

Production of ILC by rainbow trout AK leucocytes stimulated by exposure to either free or CMA IHN virus increased as MOI increased, reached a peak at an intermediate $\mathrm{MOI}$, and declined at higher MOI. The peak responses of leucocytes of individual fish to free and CMA virus were generally similar: peak activities were somewhat higher for free virus-stimulated leucocytes of 3 fish (Fig. 4A, B and 1 fish not shown) and somewhat higher for CMA virus-stimulated leucocytes of 2 fish (Fig. $4 \mathrm{C}$ and 1 fish not shown). Leucocytes cultured with uninfected, fixed CHSE cells did not produce ILC activity.

Stimulation of AK leucocytes by Poly $\mathrm{I}: \mathrm{C}$ over a range of doub.ing doses from 6.2 to $50 \mathrm{\mu g} \mathrm{ml}^{-1}$ resulted in a linear increase in ILC yield (Fig. 5).

\section{Production of ILC activity by adherent and nonadherent leucocytes}

Nonadherent leucocytes from the AK of rainbow trout ( $\mathrm{n}=4 \mathrm{fish}$ ) incubated in polypropylene tubes for 24 h with Poly I:C produced little ILC activity $15.5 \pm$
Table 1. Resistance to low $\mathrm{pH}$ of interferon-like cytokine (ILC) activities $\left(\mathrm{TCPD}_{50} \mathrm{U} \mathrm{ml}^{-1}\right.$ ) induced by free IHN virus or by cell membrane associated (CMA) IHN virus

\begin{tabular}{|c|c|c|c|c|c|c|}
\hline \multirow[t]{3}{*}{ Fish } & \multicolumn{6}{|c|}{ Inducer and treatment of supernatant ${ }^{a}$} \\
\hline & \multicolumn{3}{|c|}{ Free virus-induced } & \multicolumn{3}{|c|}{ CMA virus-ınduced } \\
\hline & Control & $\mathrm{pH} 2.0$ & $1 \%$ retained & Control & $\mathrm{pH} 2.0$ & $1 / \%$ retained \\
\hline 1 & 370 & 300 & 81.1 & 290 & 175 & 60.3 \\
\hline 2 & 460 & 305 & 68 & 280 & 120 & 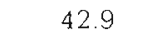 \\
\hline 3 & 140 & 104 & 74.3 & 175 & 103 & 9 \\
\hline 4 & 165 & 129 & 78.2 & 200 & 123 & 61.5 \\
\hline 5 & 118 & 98 & 83.1 & 113 & 62 & 54.9 \\
\hline $\begin{array}{l}\text { Mean } \\
\text { SE }\end{array}$ & & & $\begin{array}{r}76.6 \\
3.0\end{array}$ & & & $\begin{array}{r}55.7 \\
7.6\end{array}$ \\
\hline \multicolumn{7}{|c|}{$\begin{array}{l}\text { "Supernatants from paired cultures of rainbow trout AK leucocytes (from } \\
\text { the same individual fish) stimulated by the } 2 \text { inducers were treated over- } \\
\text { night at } \mathrm{pH} 2 \text {; matched control supernatants were maintained at } \mathrm{pH} 7.6 \text {. } \\
\text { All supernatants were treated with UV light to inactivate residual IHN } \\
\text { virus (necessary for control supernatants induced by free virus) or to } \\
\text { provide for uniformity of treatment (all other supernatants). The percent- } \\
\text { age of activity retained after low } \mathrm{pH} \text { treatment was estimated as (activity } \\
\text { after } \mathrm{pH} 2 \text { treatment/activity of control) } \times 100 \text {. Free-virus-induced super- } \\
\text { natants retained significantly (p<0.001, paired t-test) more activity after } \\
\text { low } \mathrm{pH} \text { treatment than CMA-virus-induced supernatants }\end{array}$} \\
\hline
\end{tabular}

2.8 $\mathrm{TCPD}_{50} \mathrm{U} \mathrm{ml}^{-1}$ ); unseparated cell suspensions from the same fish produced significantly higher activity (113 $\pm 15.3 \mathrm{U} \mathrm{ml}^{-1} \mathrm{p}<0.01$, paired $t$-test). Similar results were obtained when nonadherent and unseparated leucocytes ( $n=4$ fish) were stimulated with CMA IHN virus (production of $47.2 \pm 27.4$ and $262 \pm 116 \mathrm{U}$ $\mathrm{ml}^{-1}$, respectively), although the difference was not significant ( $p=0.12$, paired $t$-test) due to high variance in ILC production. Poly I:C stimulation of adherent cells remaining in tissue culture plates after removal of nonadherent cells produced little ILC activity; the low activity in these supernatants was believed to result from absorption of ILC activity on the tissue culture plates.

To compare ILC production by adherent, nonadherent, and unseparated AK leucocytes under identical

Table 2 [LC activity $\left(\mathrm{TCPD}_{50} \mathrm{U} \mathrm{m}^{-1}\right.$, mean $\left.\pm \mathrm{SE}\right)$ remaining after overnight incubation of ILC-containing supernatants in polypropylene tubes, tissue culture plates, or tissue culture plates containing monolayers of glutaraldehyde-fixed CHSE cells. Cytokines were produced by rainbow trout AK leucocytes stimulated by Poly I:C, free IHN virus, or CMA IHN virus. nd: not done

\begin{tabular}{|c|c|c|c|c|c|c|c|c|c|}
\hline \multirow{3}{*}{ Trial $^{\mathrm{a}}$} & \multirow{2}{*}{\multicolumn{3}{|c|}{ Poly I:C }} & \multicolumn{3}{|c|}{ Inducer - } & \multirow{2}{*}{\multicolumn{3}{|c|}{ CMA IHN virus }} \\
\hline & & & & & IHN vix & & & & \\
\hline & Tube & Plate & CHSE & Tube & Plate & CHSE & Tube & Plate & CHSE \\
\hline $1(4)$ & $325 \pm 9$ & $22.8 \pm 11$ & nd & nd & nd & nd & nd & nd & nd \\
\hline $2(4)^{\mathrm{D}}$ & nd & nd & nd & 400 & 290 & nd & 270 & 142 & nd \\
\hline $3(2)$ & $278 \pm 96$ & $9.5 \pm 1$ & $118 \pm 32$ & $154 \pm 24$ & $59 \pm 11$ & $82 \pm 23$ & $211 \pm 31$ & $78 \pm 42$ & $150 \pm 25$ \\
\hline Plate/Tube (\%) & $(100)$ & 5.2 & 42.4 & $(100)$ & 55.4 & 53.2 & $(100)$ & 44.8 & 71.1 \\
\hline
\end{tabular}




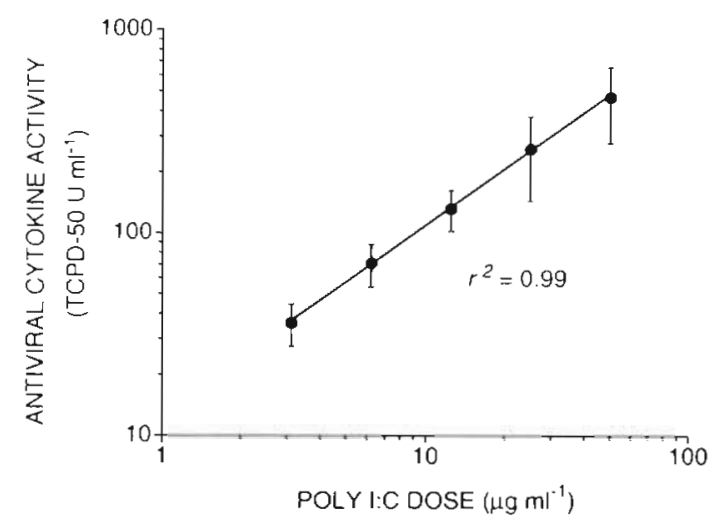

Fig. 5. Production of ILC activity by AK leucocytes of rainbow trout $(n=5)$ stimulated by Poly I:C

conditions, matched cultures of the 3 cell populations were maintained in polypropylene beakers and stimulated for $24 \mathrm{~h}$ by Poly $\mathrm{l}: \mathrm{C}$ or, in a second trial, by firee IHN virus. In the trial with Poly I:C, examination of stained cell preparations indicated that adherent cells were enriched for macrophages $125 \%$ vs $9.3 \%$ of nonadherent cells and $17 \%$ of unseparated cells) and moderately depleted in neutrophils $(39 \%$ vs $55 \%$ of nonadherent cells and $39 \%$ of unseparated cells). Numbers of lymphocytes were identical in adherent and nonadherent cultures (35\% vs $35 \%$ of nonadherent cells and $42 \%$ of unseparated cells). The ILC activities produced by adherent, nonacherent and unseparated cell populations were highly correlated $\left(\mathrm{r}^{2}=0.91\right.$ $p<0.0001$, linear regression analysis) with percentages of macrophages in the cultures (Fig. 6).

In the trial with IHN virus as inducer, adherent cell populations were enriched for macrophages $(17 \%$ vs $7.5 \%$ of nonadherent cells and $11 \%$ of control), moderately depleted in neutrophils $(14 \%$ vs $26 \%$ of non-

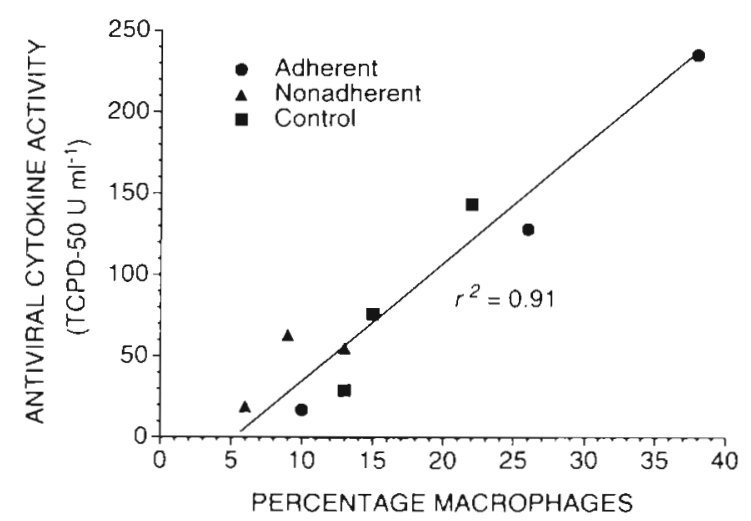

Fig. 6. Percentages of macrophages in cultures of adherent $(\bullet)$, nonadherent (4), and unseparated (-) leucocytes prepared from the AK of 3 rainbow trout, and corresponding ILC activities induced by $24 \mathrm{~h}$ stmulation with Poly I:C

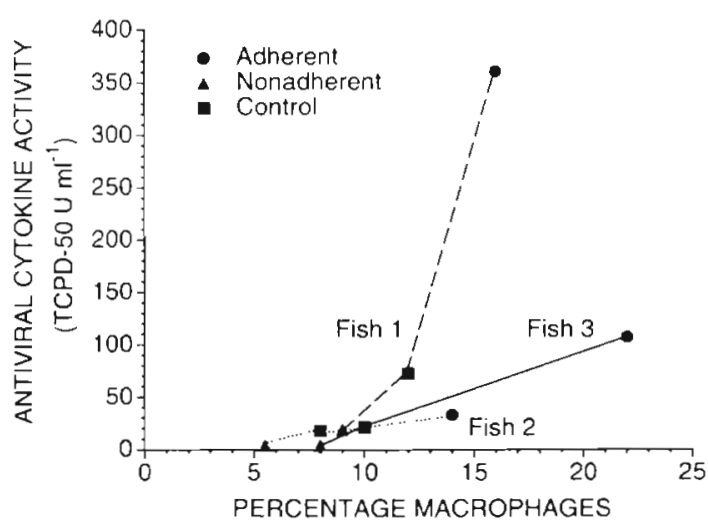

Fig. 7. Percentages of macrophages in cultures of adherent

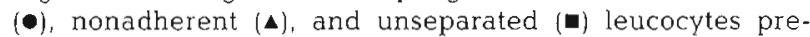
pared from the AK of 3 rainbow trout and corresponding llC activities induced by $24 \mathrm{~h}$ stimulation with free IHIN virus

adheseni cells and $24 \%$ of control), with no change in the prevalence of lymphocytes $(67 \%$ vs $68 \%$ in nonadherent cells and $67 \%$ in unseparated cells.) Production of ILC activity by the 3 cell populations differed significantly ( $p=0.05$, Friendman's 2 -way rank test), with adherent cell populations producing higher activity than control or nonadherent cell populations (respectively $167 \pm 99,37 \pm 18$, and $7.7 \pm 5.8 \mathrm{TCPD}_{50} \mathrm{U}$ $\mathrm{ml}^{-1}$ ). Macrophages from one of the fish responded to induction by IHN virus much more strongly than macrophages from the remaining 2 fish (Fig. 7 ).

\section{DISCUSSION}

High inter-assay coefficients of variation are typical for interferon assays (Finter 1981, Rogel-Gaillard et al. 1993), even when careful precautions are taken to maintain experimental conditions as constant as possible. We found that much $(68 \%)$ of the inter-assay variation in ILC titers estimated for a laboratory reference standard was related to inter-assay variation in $O D$ ranges (maximum OD - minimum $O D$ ) of stained CHSE cells. A similar relationship between the density of target cells and measured titers of another cytokine, tumor necrosis factor, was reported for a spectrophotometric assay characterized by Flick \& Gifford (1984). In our study, the relationship between ILC titer and OD range was one of directly inverse proportionality, so that titers for samples and reference standards assayed on tissue culture plates with varying OD ranges could be standardized by the factor (observed plate $O D$ range/standard plate $O D$ range). This adjustment of estimated titers greatly reduced intra-assay and interassay variation and is recommended as a routine practice for spectrophotometric estimation of ILC activity. Direct proportionality between ILC titer and OD range 
should, however, be confirmed for assay systems using cell-virus combinations other than the one described here.

Standardization of ILC titers to correct for OD differences between plates does not alleviate the need to inciude a laboratory reference standard (RS) with each assay (Finter 1981, Renault et al 1991), because the sensitivity of cultured cells to the protective effects of ILC or to the cytopathic effects of the challenge virus may change over time. By adjusting titers to correspond to a standard OD range and also correcting by the factor (multiple-assay mean for RS)/(RS value for particular assay), inter-assay coefficients of variation in our study were reduced from the 40 to $50 \%$ range to about $10 \%$.

An improvement was made in earlier procedures for estimating the ILC dilution providing $50 \%$ protection to treated cell monolayers. Plotting of log percent protection against $\log$ ILC dilution (Renault et al. 1991, Rogel-Gaillard et al. 1993) produces a sigmoid curve, allowing the use of only 2 data points near the middle of the curve. We found that plots of probit percent protection against log ILC dilution were linear over a wide range, deviating from linearity only above $95 \%$ and below $5 \%$ protection. After log-probit transformation, 4 or 5 data points fell on the linear portion of the curve, improving the accuracy with which titers could be estimated. The linear relationships observed with logprobit transformed data indicate that the responses of individual CHSE cells to ILC treatment follow a lognormal distribution, with some individual cells gaining protection against viral challenge after treatment with relatively high ILC dilutions and others responding only to treatment with much lower dilutions.

Anterior kidney leucocytes produced maximum ILC activity after $24 \mathrm{~h}$ stimulation by Poly I: C, but activity produced by IHN virus continued to increase for $72 \mathrm{~h}$, the longest interval used. This difference in the kinetics of ILC induction presumably reflects differences in the processes involved in induction, as well as continuing amplification of ILC induction by infection of additional AK leucocytes after repeated cycles of IHN virus replication. Although higher ILC titers were obtained after 48 or $72 \mathrm{~h}$ stimulation with IHN virus than after $24 \mathrm{~h}$, the magnitude of the early ILC response may be a better indication of the potential effect on the course of incipient viral infection in vivo.

Poly I:C-induced IFN production by mammalian leucocytes is primarily attributable to one cell type, the macrophage (reviewed by Neuman 1982), and macrophages are largely responsible for the antiviral state induced in mice by Poly I:C inoculation (Martinez et al. 1980). Viruses, on the other hand, can induce IFN$\alpha / \beta$ production by many cell types. Some mammalian viruses preferentially induce IFN production by macro- phages or by lymphocytes, but the capacity of the various types of fish leucocytes for virus-induced ILC production has not been previously investigated. We found that adherence of rainbow trout AK leucocytes to tissue culture plates removed the cell fraction(s) capable of ILC production. Adherence of rainbow trout AK leucocytes to tissue culture plates removes most macrophages, but many neutrophils and lymphocytes, possibly representing distinct subpopulations of these cell types, are also adherent (Congleton et al. 1990). More specific evidence for the role of macrophages in ILC production was provided by the demonstration that adherent cell populations enriched for macrophages, but not for neutrophils or lymphocytes, produced significantly more ILC activity than nonadherent cell populations when stimulated by IHN virus. Furthermore, production of ILC activity in Poly I:Cstimulated cultures was proportional to the number of macrophages present. These results indicate that macrophages were responsible for much of the ILC activity produced by IHN virus- and Poly I:C-stimulated AK leucocytes.

Rainbow trout AK leucocytes stimulated at increasing multiplicities of infection (MOI) with either free infectious IHN virus or CMA inactivated virus responded by producing increasing amounts of ILC until a peak was reached; at higher MOI, ILC production declined. Dose-response curves for free and CMA virus are not directly comparable, because MOI were necessarily estimated differently: In trials with free virus, the MOI was estimated as the ratio virus PFU: leucocytes; in trials with CMA virus, the MOI was estimated as the ratio virus PFU:target (CHSE) cells. The CHSE cells were fixed after overnight culture and used to stimulate leucocytes for ILC production, but the density of virions present on the CHSE cell membranes was not known. Nevertheless, peak yields at the optimal MOI for the 2 inducers can be compared, and were generally similar. Although some of the activity produced by CMA virus-stimulated AK leucocyte cultures was lost by absorption to tissue culture plates, the loss should not have exceeded $30 \%$ (Table 2 ).

The dome-shaped dose-response curves for ILC induction by free and CMA IHN virus are similar to the type ' $r=1$ ' virus dose-IFN response curve described by Marcus (1986). This induction curve is best modeled by a curve generated by assuming that cells stimulated by 1 inducing particle produce a full yield of IFN, but that cells stimulated by 2 or more particles produce little or no IFN. The reason for suppression of IFN production in cells stimulated simultaneously by 2 or more virus particles is not known (Marcus 1986). Our data showing in vitro suppression of ILC production at higher MOI suggest that similar suppression may occur in vivo in heavily infected kidneys of salmonid fish. 
Stimulation of ILC production by exposure of rainbow trout $A K$ leucocytes to CMA IHN virus demonstrated that, in this system, internalization of virions and exposure or replication of viral RNA was not required for IFN induction. Rogel-Gaillard et al. (1993) previously reported that rainbow trout AK leucocytes and peripheral blood leucocytes produced ILC activity after stimulation by glutaraldehyde-fixed VHS virusinfected cells: Yields of ILC induced by CMA virus were similar to yields induced by free infectious and free inactivated virus ( $\beta$-propiolactone-treated), although no dose-response trials were done to determine optimal MOI for peak yields. Rogel-Gaillard et al. further demonstrated that the ILC response to CMA VHS virus was abolished by treatment of fixed infected cells with a monoclonal antibody to the transmembrane viral glycoprotein $G$. It has been known for some time that interaction of human lymphocytes with fixed celi membranes bearing viral antigens can be an adequate stimulus for IFN production (reviewed by Ito 1994), and recent research has shown that human monocytes and macrophages can also be stimulated to produce IFN- $\alpha$ and IFN- $\beta$ by contact with fixed infected cells or with recombinant viral envelope glycoproteins (Francis \& Meltzer 1993, Gessani el al. 1994). Induction of ILC by membrane-to-membrane contact between rainbow trout macrophages or other ILCproducing leucocytes and mature virions budding from infected cells could contribute to local resistance to IHN virus at primary sites of infection.

The antiviral activity induced in cultures of salmonid AK leucocytes by Poly I:C and IHN virus had both acid-resistant and acid-labile components, indicating the presence of 2 or more cytokine types or subtypes. Moreover, the ILC produced by AK leucocytes from the same individual fish after stimulation by free virus or CMA virus differed in acid resistance, indicating induction of cytokines in differing proportions or of differing types. Type I interferons produced by mammalian macrophages are generally acid-stable, but some subtypes of IFN- $\beta$ are acid-labile (Cohen et al. 1986). Fish ILCs characterized by other studies have shown various degrees of acid lability. Salmonid ILCs induced in vivo and in vitro by VHS virus and Poly I:C have typically been reported as acid-stable (de Kinkelin \& Dorson 1973, Eaton 1990, Renault et al. 1991, Rogel-Gaillard et al. 1993 ), although in most instances specific data on activity before and after low $\mathrm{pH}$ treatment have not been given, leaving open the possibility that some loss was observed. An ILC produced by oncogene-immortalized flatfish (Paralichthys olivaceus) lymphocytes was totally inactivated after only $20 \mathrm{~min}$ at pH 2 (Tamai et al. 1993b) The amino acid sequence homology of this cytokine with mammalian IFN- $\alpha$, IFN- $\beta$, and IFN- $\gamma$ was low (Tamai et al. 1993a). An acid-labile IFN- $\gamma$-like molecule is produced by mitogen-stimulated rainbow trout leucocytes (Graham \& Secombes 1990), but IFN- $\gamma$ is not produced by unsensitized leucocytes after stimulation by polyribonucleotides or virus, and so would not have contributed to the ILC activity reported here. These published data and the results of the present study indicate that in fish, as in mammals, several cytokines have antiviral activity.

Hematopoietic tissue in the $\mathrm{AK}$ of rainbow trout is a target tissue for IHN virus, supporting viral replication by the second or third day of infection (Yamamoto \& Clermont 1990, Yamamoto et al. 1990). The results presented here show that leucocytes isolated from the AK of rainbow trout and chinook salmon produce ILC activity when stimulated in vitro by either free or CMA IriN virus, and that a large part of this activity is produced by macrophages. This capacity may be a significant factor in nonspecific resistance to the virus in vivo. Further studies are needed to determine the capacities of other target tissues (e.g. skin, fins, and gills; Yamamoto et al. 1990, Yamamoto et al. 1992) for ILC production, and to determine if differences in these capacities are correlated with differences in in vivo resistance to the disease.

Acknowledgements. This work was supported by grants from the U.S. Department of Agriculture to the Western Regional Aquaculture Consortium (92-38500-7195, 93-38500-8588) and is contribution number 786 from the Forestry and Wildlife Resources Experiment Station. University of Idaho. The Idaho Cooperative Fish and Wildlife Research Unit is supported by the U.S. National Biological Service, the University of Idaho, the ldaho Department of Fish and Game, and the Wildlife Management Institute.

\section{LITERATURE CITED}

Burke JA, Mulcahy D (1980) Plaquing procedure for infec trous hematopoietic necrosis virus. Appl Environ Microbiol 39:872-876

Capobianchi MR, Facchini J, Marco PD, Antonelli G, Dianzani $F(1985$ ) Induction of $\alpha$ interferon by membrane interaction between viral surface and peripheral blood mononuclear cells (4204.1). Proc Soc Exp Biol Med 178:551-556

Chilmonczyk S, Winton JR (1994) Involvement of rainbow trout leucocytes in the pathogenesis of infectious hematopoetic necrosis. Dis Aquat Org 19:89-94

Cohen S, Bino T, Rosenberg H, Shaffermen A (1986) Induction and characterization of bovine leukocyte interferon Methods Enzymol 119:139-144

Congleton JL, Greenlee AR, Ristow SS (1990) Isolation of leucocytes from the anterior kidney and spleen of rainbow trout in a self-generating density gradient. J Fish Biol 36: 575-585

de Kinkelin P, Dorson M (1973) Interferon production in rainbow trout (Salmo gairdneri) experimentally infected with Egtved virus. J Gen Virol 19:125-127

de Kinkelin P, Dorson M, Hattenberger-Baudouy AM (1982) Interferon synthesis in trout and carp after viral infection. Develop Comp Immunol Suppl 2:167-174 
de Kinkelin P, Le Berre M (1974) Necrose hematopoietique infectieuse des salmonides: production d'interferon circulant induite apres l'infection experimentale de la trute arc-en-ciel (Salmo gairdneri). CR Acad Sci Paris 279: $445-448$

de Maeyer E, de Maeyer-Guignard J (1988) Interferons and other regulatory cytokines. John Wiley, New York

Eaton WD (1990) Antiviral activity in four species of salmonids following exposure to poly(I)-poly(C). Dis Aquat Org 9:193-198

Fijan N, Sulimanovic D, Bearzotti M, Muzinic D, Zwillenberg LO, Chilmonczyk S, Vautherot JF, de Kinkelin P (1983) Some properties of the epithelioma papulosum cyprinini (EPC) cell line from carp (Cyprinus carpio). Ann Inst Pasteur Virol 134:207-220

Finter NB (1981) Standardization of assays of interferons. Methods Enzymol 78:14-25

Flick DA, Gifford GE (1984) Comparison of in vitro cell cytotoxic assays for tumor necrosis factor. J Immunol Moth 68:167-175

Francis ML, Meltzer MS (1993) Induction of IFN-alpha by HIV-1 in monocyte-enriched PBMC requires gp 120-CD4 interaction but not virus replication. J lmmunol 151: $2208-2216$

Gessani S, Puddu P, Varano B, Borghi P, Conti L, Fantuzzi L, Belardelli $F(1994)$ Induction of beta interferon by human immunodeficiency virus type 1 and its gp120 protein in human monocytes-macrophages: role of beta interferon in restriction of virus replication. J Virol 68:1983-1986

Graham S, Secombes CJ (1990) Do fish lymphocytes secrete interferon- $\gamma$ ? J Fish Biol 36:563-573

Gresser I (1984) Role of interferon in resistance to viral infection in vivo. In: Vilcek J, De Maeyer E (eds) Interferon 2: interferons and the immune system. Elsevier, Amsterdam, p 221-247

Ito $Y$ (1994) Induction of interferon by virus glycoprotein(s) in lymphoid cells through interaction with the cellular receptors via lectin-like action: an alternative interferon induction mechanism. Arch Virol 138:187-198

LaPatra SE, Lauda KL, Morton AW (1991) Antigenic and virulence comparison of eight isolates of infectious hematopoietic necrosis virus from the Hagerman Valley, Idaho, USA. In: Proc 2nd Int Symp Viruses Lower Vert. Oregon State University Press, Corvallis, p 125-132

MacDonald RD. Kennedy C (1979) IPN virus persistently infects chinook salmon embryo cells independently of interferon. Virology 95:260-264

Marcus PI (1986) Interferon induction: dose-response curves. Methods Enzymol 119:106-114

Martinez D, Lynch R.J, Meeker JB, Field AK (1980) Macro-

Responsible Subject Editor: F. M. Hetrick, College Park, Maryland, USA phage dependence of polyribonosmuc acid-polymbocytidylic acid-induced resistance to herpes simplex virus infection in mice. Infect Immun 28:147-153

Morahan PS, Pinto A, Stewart D, Murasko DM, Brinton M (1991) Varying role of $\alpha / \beta$ interferon in the antiviral efficacy of synthetic immunomuodulators ayanst Simlık Forest virus infection. Antivir Res 15:241-254

Müller U, Steinhoff U, Reıs LIL, Hemmi S, Pavlovic J, Zinkernagel RM, Aquet M (1994) Functional role of type 1 and type II interferons in antiviral defense. Science 264: 1918-1924

Neumann C (1982) Mononuclear phagocytes as producers of interferon. Lymphokines 7:165-201

Renault T, Torchy C, de Kinkelin P (1991) Spectrophotometric method for titration of trout interferon, and its application to rainbow trout fry experimentally infected with viral haemorrhagic septicaemia virus. Dis Aquat Org 10:23-29

Rogel-Gaillard C, Chilmonczyk S, de Kinkelin P (1993) In vitro induction of interferon-like activity from rainbow trout leucocytes stimulated by Egtved virus. Fish Shellfish Immunol 3:383-394

Sprague JB (1969) Measurement of pollutant toxicity to fish. I. Bioassay methods for acute toxicity. Water Res 3:793-821

Tamai T, Shirahata S, Noguchi $T$, Sato N, Kimura S, Murakami $H$ (1993a) Cloning and expression of flatfish (Paralichthys olivaceus) interferon cDNA. Biochim Biophys Acta 1174:182-186

Tamai T, Shirahata S. Sato N, Kimura S, Nonaka M, Murakami H (1993b) Purification and characterization of interferon-like antiviral protein derived from flatfish (Parahchthys olvaceus) lymphocytes immortalized by oncogenes. Cytotechnology 11:121-131

Winton JR (1991) Recent advances in detection and control of intectious hematopoietic necrosis virus in aquaculture. A. Rev Fish Dis 1992:83-93

Wolf K (1988) Fish viruses and fish viral diseases. Cornell University Press, Ithaca, New York, p 83-114

Yamamoto I, Batts WN, Arakawa CK, Winton JR (1990) Multiplication of infectious hematopoietic necrosis virus in rainbow trout following immersion infection: whole-body assay and immunohistochemistry. J Aquat Anim Health 2:271-280

Yamamoto T, Batts WN, Winton JR (1992) In vitro infection of salmonid epidermal tissues by infectious hematopoietic necrosis virus and viral hemorrhagic septicemia virus. $J$ Aquat Anim Health 4:231-239

Yamamoto T, Clermont TJ (1990) Multiplication of infectious hematopoietic necrosis virus in rainbow trout following immersion infection: organ assay and electron microscopy, $J$ Aquat Anim Health 2:261-270

Manuscript first received: September 18, 1995 Revised version accepted: November 29, 1995 